\title{
Irreconcilable Differences: the International Whaling Commission and Cetacean Futures
}

Final version: http://onlinelibrary.wiley.com/doi/10.1111/j.1541-1338.2011.00529.x/full

The International Whaling Commission was mandated to protect the whaling industry back in 1946. As the threat of extinction for several species of cetaceans rose and whales assumed a prominent space in public environmental consciousness, the IWC gradually swung towards an anti-whaling position, led by the United States and some key European states. A moratorium on whaling was passed by three-fourths majority vote in 1982, with exceptions for "aboriginal" and "scientific" whaling. The decision was never taken well by several whaling states, including Norway, Japan, Iceland and others. A diplomatic war has erupted, complete with development assistance weaponry and public chastisement, but the battle has rarely entered the economic realm, despite threats from the United States that it would utilize various pieces of legislation permitting the application of sanctions related to marine mammal protection. Now that Iceland has made it clear it wishes to continue a small hunt, anti-whaling advocates are clamoring for the Obama Administration to apply sanctions. The main concern here seems to be that Iceland has resumed hunting Fin whales, the second largest of the great whales (and indeed the second largest mammal on earth), still considered endangered by most counts.

Just as fishing net entanglements are serious threats to whales and other marine species, the IWC has been entangled in an ideological net for nearly half a century. Put simply, a sharp division persists between the "preservationist" states and NGOs, who wish to ban all whaling in perpetuity, and the "conservationist" (or, as they prefer, "pro-sustainable use")states such as Japan, Iceland, and Norway, which advocate a controlled whale hunt and indeed engage in small-scale whaling today due to legal reservations and the scientific whaling clause. Meanwhile the United States, which permits its aboriginal groups to whale, is accused of hypocrisy as it pursues the preservationist position abroad. Some states, such as Canada, have withdrawn from the IWC because of the moratorium, even though Canada has very little aboriginal whaling activity itself. It is a small diplomatic miracle that Japan, by the far the most vocal and powerful critic of the current regime, has not withdrawn from the IWC, choosing instead to work abnormally hard to change it from within. Anyone who has been to an IWC or CITES meeting has seen the expensive effort the Japanese make to get their point of view across in the hallways: this has included whale meat barbeques and videos elaborating on the protein needs of the world.

Indeed the IWC Annual Meeting (with 89 members, including landlocked states, at the time of writing) is a strange place, where the international media spotlight burns unusually bright for a multilateral resource agreement forum, and where frustrated diplomats and scientists on both sides of the divide mingle and leave with the requisite expressions of exasperation on their faces. One day, at the most recent IWC Annual Meeting in the British Isles, the Committee spent time discussing the fate of the western North Pacific gray whale (population roughly 130) and recommending a comprehensive protection plan, including possible costly blockages of oil and gas exploration and development. It then moved on to a presentation by Norway on the use of a new penthrite harpoon grenade which has decreased the average time of death to two minutes after striking the mammal, ideally destroying its 
large brain stem without damaging too much meat. This surreal juxtaposition takes shape within a usually diplomatic context. But when it comes to establishing sanctuaries or dropping what has been in effect a moratorium on commercial whaling, the gloves come off.

Efforts to establish a Revised Management Scheme (or RMS -- based in turn on a proposed Revised Management Procedure for estimating whale stocks and advising catch limits) have consistently failed because of the irreconcilable differences between the two groups. Implicit in the polarity is a deep critique of the other: on the one side, preservationists argue that conservationists are a throwback to previous years, before we had evolved into a higher form of environmental consciousness; on the other, conservationists point to the grating hypocrisy of the biggest polluters and meat consumers on earth telling them how to conduct themselves on the high seas. Aboriginal whaling, permitted in the United States, is another bone of contention, since the Japanese arguer their coastal communities also have a deep-running affinity to whaling as a cultural mainstay. (The United States even threatened sanctions against Canada once, since the Inuit conduct a small bowhead hunt each year and Canada permits this without belonging to the IWC; this is yet another story.) Of course Norway as always occupies a special place here, since it is generally recognized as a key state in terms of promoting sustainable development, and yet retains its unlikable predilection for hunting whales and shipping whale meat to Japan.

The latest annual meeting of the IWC ended much like every meeting has in the preceding three decades: in diplomatic disarray. An effort to establish a South Atlantic Whaling Sanctuary by Brazil and Argentina was scuttled when it became obvious that many conservationist states were unwilling to even vote on the issue (it will resurface next year, however, in Panama). The ban on commercial whaling remains intact for all species, and aboriginal whaling quotas were newly established. Scientific whaling, in which the Japanese pretend to kill whales for the purpose of advancing our knowledge about the state of whale populations, will continue. So too will a perfectly legal hunt by Norway and Iceland, both of whom have lodged an objection to the zero quota and are thereby permitted (unless the Sea Sheppard or some other group physically stops them) to conduct it.

Iceland's intention to resume a Fin hunt is hardly surprising, given its whaling history and troubled relationship with the IWC. Iceland did not lodge a formal objection back in the early 1980s when the zero-catch quota was introduced, and had limited success obtaining scientific whaling permits in subsequent years. It withdrew from the IWC altogether in 1992, opting instead to help form another commission for marine mammal management, but then rejoined, fearful that non-IWC whaling would mean trading with Japan would be stopped, and only after an especially convoluted diplomatic and voting process (yes, even for the IWC, this one was a mess). When it rejoined, however, it managed to do so with a formal reservation stipulating that it would resume limited commercial whaling in several years, and Iceland resumed a small hunt in 2006, which included a Fin whale. Recently however it has increased its self-proclaimed fin whale quota to 150 mammals, which is certainly high considering the endangered status of the Fin whale. Sources say the RMS, were it in place, would have recommended a substantially lower catch; this should be seen as a reason for dropping the moratorium and adopting the RMS, but this seems beyond the ideological horizon of the preservationists. Thus the pressure for Obama and company to enact the so-called "Pelly Amendment" which would permit leveling sanctions on Iceland. Of course, Obama may be excused for having bigger fish to fry (sorry - and whales are not 
fish), but there are signs the administration is taking the option seriously and could make an announcement soon.

The sanctions, in the unlikely event that they are imposed, may have an effect in the short run, forcing cash-strapped Iceland to rethink its strong advocacy of whaling. Indeed the very seriousness of the sanctions will probably result in a lowering of the self-quota for Fin whales. However, we have seen throughout the history of the whaling issue-area that there are limitations to efforts to convince conservationist states such as Iceland and Japan to change their perspective and gravitate toward the preservationist position. Another organization, the North Atlantic Marine Mammal Organization, is favoured by Iceland, Norway and others because it does not impose what is viewed as a normatively imperialist mandate, but it cannot overwrite IWC regulations according the UN Law of the Sea. Meanwhile, within the IWC, which is always strained to the breaking point yet somehow surfaces intact each year, there is no consensus whatsoever on the future of whaling or the value of American sanctions. While the divisions within the IWC can only be hardened by whaling-related sanctions, proponents argue that there is little to lose and much to gain by publicly chastising Iceland. However, efforts to establish a compromise regime which allows limited small-scale commercial whaling (the only conceivable long-term solution in my view) will be further hampered if such sanctions are imposed.

Meanwhile, we should step back a moment and examine the broader picture here. A return to largescale commercial whaling is simply not possible. Even if protein-starved millions were somehow convinced that importing and eating whale meat would provide their nutrition needs (this occurred, to some extent, in Japan following World War Two) it is unlikely the majority of the states in the IWC would support anything approaching a large hunt, and even then it would be subject to an RMS that takes shifting populations into account. Put bluntly, outside Japan and perhaps Norway, there is a very limited market for whale meat (and it would not make economic sense to hunt whales for their blubber or other properties which were substituted by modern products many decades ago). In short, there would be very little profit motive to rekindle what was already a heavily subsidized industry when it started dying off in the 1960s and 1970s. Though some populations have recovered, most of the great whales do not have populations that could sustain even a limited hunt, which is reflected in the CITES Appendices (a notable exception is the Pacific Grey Whale, which has recovered, and is hunted by an American aboriginal group, but remains -politically -- on Appendix I). Of course the whale will remain a potent symbol for environmentalists, not only because of the folly of the industrialized past, but because whales are, well... whales: majestic, intelligent, mysterious, extra-large charismatic vertebrae. Even in Japan, whale-watching is profitable, though you can watch whales in the afternoon and then eat them for dinner.

Though animal welfare activists and others are rightfully concerned about whaling, and about cetacean captivity programs and the trade in live specimens, the big threat to these animals is the alteration and destruction of their habitat. Climate change and overfishing are conspiring to forever change the oceans. Industrial and agricultural waste, coral reef bleaching, temperature shifts, shipping noise, oil and natural gas operations, invasive species: all of these are greater longer-term threats than the resumption of small-scale whaling. We need to focus our attention on the habitat of cetacean populations (including 
polluted rivers, where dolphins and small whales such as the beluga are especially at risk), instead of addressing cetacean survival through the emotionally charged lenses of whaling politics. We need to wed the public imagination's view of the endangered whale to the survival of the oceans and rivers on which we all depend for life and sustenance, and this includes acting on the need for rigorous selfassessments of our own contributions to the present oceans crisis.

To its credit, the IWC has been studying these questions for many years (though there is another endless side dispute over whether it has any jurisdiction over dolphins). But so have hundreds of universities, NGOs, government bodies, independent cetologists and marine biologists, and others. This is where the real progress must be made in the future, and even though the media loves a good fight, and the endless debate at the IWC can be a very entertaining spectacle, we need to move onward. Permitting the RMS to fall into place would be viewed as a catastrophic defeat by many, but it would also represent a genuine opportunity to manage whaling and treat whales as an international resource. But it is unlikely this will happen, given the entrenchment of the positions outlined above, and the resulting media circus and diplomatic warfare will continue to overshadow the larger crisis threatening cetacean futures. 